\title{
Effects of Prolonged Ethanol Intake: Production of Fatty Liver Despite Adequate Diets*
}

\author{
Charles S. Lieber, $†$ Don P. Jones, and Leonore M. DeCarli \\ (From the Thorndike Memorial Laboratory and the Second and Fourth [Harvard] Medical \\ Services, Boston City Hospital, the Department of Medicine, Harvard University, \\ Boston, Mass.; the Liver Disease and Nutrition Unit, Second [Cornell] \\ Medical Division, Bellevue Hospital, and the Department of \\ Medicine, Cornell University Medical College, \\ New York, N. Y.)
}

Although the association of alcoholism and fatty liver was described as early as 1836 (3), the pathogenesis of this disorder is still the subject of controversy. Among the problems at issue is the question of whether the fatty liver observed after prolonged alcohol intake is due only to nutritional deficiencies associated with alcoholism or whether it is caused by alcohol itself (4-6).

In the present study an attempt was made to dissociate the effect of ethanol per se from sequelae of dietary deficiencies. It was found, both in man and in rats, that ethanol ingestion produces fatty livers, despite maintenance of adequate diets.

\section{Methods}

\section{A. Clinical studies}

Subjects. Five individuals were studied under metabolic unit conditions. The subjects varied in age between 36 and 62 years; all but one were males. All had a history of alcoholism, but they had abstained from alchohol for periods varying from 30 days to 2 years. At the time of the study, none had clinical evidence of liver disease, and liver function tests were normal ( Table I). The subjects had a history of previous alcoholic fatty liver, documented by liver biopsy, but at the time of

* Submitted for publication October 16, 1964 ; accepted February 25, 1965.

Presented in part at the 76th Annual Meeting of the Association of American Physicians (1) and the Annual Meeting of the American Association for the Study of Liver Diseases (2).

Supported in part by the U. S. Army Medical Research and Development Command, Department of the Army contract DA-49-193-MD-2013, and U. S. Public Health Service research grant AM 06284 from the National Institute of Arthritis and Metabolic Diseases.

† Recipient of a U. S. Public Health Service Research Career Development Award (1-K3-AM-22,590) from the National Institute of Arthritis and Metabolic Diseases. Address requests for reprints to Dr. Charles S. Lieber, Liver Disease and Nutrition Unit, Second (Cornell) Medical Division, Bellevue Hospital, New York, N. Y. the study, liver morphology had returned to normal, as indicated by the biopsies done during the control periods (Figures 2a, 3a, 4a, and 5a).

Diets and procedure. The composition of the diet will be indicated individually with the results. Four individuals received solid conventional foods, and one subject (No. 3) was given a liquid diet, containing sucrose as carbohydrate. All the diets had an adequate content of nutrients, including amounts of vitamins and minerals above the daily recommended allowances (7). Special care was given to the maintenance of constant food intake, both during the control and ethanol periods; dietary consumption varied between 90 and $100 \%$ of the food administered, and the individuals maintained stable body weights during the entire study (Table I). After control periods, alcohol, 1 considered to have a caloric value of 7 calories per $g$ (7), was administered divided in five or six daily doses, either as blended whiskey (four individuals) or, in the subject given the liquid diet, as laboratory ethanol. It was either isocalorically substituted for carbohydrate given during the control period (Subjects 1 to 3 ) or added to the normal diet (Subjects 4 and 5). The dose and duration of alcohol administration will be indicated individually for each subject with the results. The amounts given produced mild euphoria, without gross intoxication. Liver biopsies were performed during the control periods and after various intervals of ethanol administration. In Subjects 3 and 4, liver biopsies were also done approximately 1 month after ethanol withdrawal.

Chemical assays. Blood samples were collected in the morning with subjects in the fasting state before alcohol administration, unless otherwise indicated. Blood samples were centrifuged within 2 hours after collection, and the heparinized plasma or serum was immediately frozen at $-18^{\circ} \mathrm{C}$ until analysis. Serum alcohol was determined by the method of Newman and Newman (8). For the analysis of glycerides, $1 \mathrm{ml}$ of plasma was extracted with chloroform-methanol (9), the phospholipids were adsorbed on small silicic acid columns, and the glycerides were measured in the eluant (10). Determinations were also done of plasma glucose, blood hematocrit, amylase, and liver function tests, both during the control periods and after various intervals of ethanol administration.

1 "Alcohol" as used in this paper is synonymous with ethyl alcohol or ethanol. 
TABLE I

Liver function tests and body weight in five subjects given ethanol under metabolic ward conditions

\begin{tabular}{|c|c|c|c|c|c|c|c|c|}
\hline $\begin{array}{c}\text { Subject } \\
\text { no. }\end{array}$ & Period & Bilirubin & SGOT* & $\begin{array}{l}\text { Thymol } \\
\text { turbidity† }\end{array}$ & $\underset{\text { protein }}{\text { Total }}$ & Albumin & $\begin{array}{c}\text { Prothrombin } \\
\text { timef }\end{array}$ & Body wt \\
\hline 1 & $\begin{array}{l}\text { Control period } \\
\text { After } 9 \text { days } \\
\text { After } 18 \text { days }\end{array}$ & $\begin{array}{c}m g / 100 m l \\
0.8 \\
1.0 \\
0.7\end{array}$ & $\begin{array}{l}27 \\
32 \\
37\end{array}$ & $\begin{array}{l}1.0 \\
1.5 \\
1.5\end{array}$ & $\begin{array}{c}\mathrm{g} / 100 \mathrm{ml} \\
6.9 \\
7.0 \\
7.1\end{array}$ & $\begin{array}{c}\mathrm{g} / 100 \mathrm{ml} \\
4.2 \\
4.0 \\
3.7\end{array}$ & $\begin{array}{l}14.0(14.0) \\
13.8(13.0) \\
15.1(14.0)\end{array}$ & $\begin{array}{c}\text { kg } \\
82.4 \\
82.8 \\
82.4\end{array}$ \\
\hline 2 & $\begin{array}{l}\text { Control period } \\
\text { After } 11 \text { days } \\
\text { After } 17 \text { days }\end{array}$ & $\begin{array}{l}1.0 \\
0.8 \\
1.2\end{array}$ & $\begin{array}{l}24 \\
32 \\
27\end{array}$ & $\begin{array}{l}1.0 \\
1.2 \\
1.3\end{array}$ & $\begin{array}{l}6.8 \\
7.0 \\
6.0\end{array}$ & $\begin{array}{l}4.7 \\
4.6 \\
4.2\end{array}$ & $\begin{array}{l}15.2(14.0) \\
14.8(13.2) \\
15.0(13.7)\end{array}$ & $\begin{array}{l}69.8 \\
70.0 \\
70.7\end{array}$ \\
\hline \multirow[t]{2}{*}{3} & $\begin{array}{l}\text { Control period } \\
\text { After } 10 \text { days }\end{array}$ & $\begin{array}{l}0.2 \\
0.4\end{array}$ & $\begin{array}{l}18 \\
26\end{array}$ & $\begin{array}{l}1.5 \\
1.5\end{array}$ & $\begin{array}{l}7.4 \\
7.0\end{array}$ & $\begin{array}{l}4.3 \\
3.9\end{array}$ & $\begin{array}{l}13.2(13.2) \\
13.0(13.0)\end{array}$ & $\begin{array}{l}71.5 \\
71.4\end{array}$ \\
\hline & ethanol withdrawal & 0.2 & 11 & 2.3 & 6.8 & 3.8 & $14.8(14.0)$ & 72.4 \\
\hline 4 & $\begin{array}{l}\text { Control period } \\
\text { After } 7 \text { days } \\
\text { After } 11 \text { days }\end{array}$ & $\begin{array}{l}0.8 \\
1.0 \\
1.1\end{array}$ & $\begin{array}{l}30 \\
42 \\
30\end{array}$ & $\begin{array}{l}1.1 \\
2.2 \\
1.8\end{array}$ & $\begin{array}{l}6.8 \\
7.2 \\
7.2\end{array}$ & $\begin{array}{l}3.8 \\
3.9 \\
3.8\end{array}$ & $\begin{array}{l}15.2(13.0) \\
14.6(13.2) \\
15.8(14.0)\end{array}$ & $\begin{array}{l}84.3 \\
85.2 \\
85.3\end{array}$ \\
\hline 5 & $\begin{array}{l}\text { Control period } \\
\text { After } 11 \text { days } \\
\text { After } 25 \text { days }\end{array}$ & $\begin{array}{l}1.1 \\
0.9 \\
1.0\end{array}$ & $\begin{array}{l}40 \\
22 \\
27\end{array}$ & $\begin{array}{l}1.8 \\
1.1 \\
1.2\end{array}$ & $\begin{array}{l}7.1 \\
7.3 \\
7.0\end{array}$ & $\begin{array}{l}3.7 \\
3.9 \\
3.9\end{array}$ & $\begin{array}{l}15.2(13.8) \\
15.0(13.2) \\
15.8(14.0)\end{array}$ & $\begin{array}{l}54.1 \\
53.5 \\
54.6\end{array}$ \\
\hline
\end{tabular}

* Serum glutamic oxaloacetic transaminase; normal range, 8 to $40 \mathrm{U}$.

$\dagger$ Normal range, 0 to 4 Maclagan U.

$\ddagger$ In seconds (with control values).

\section{B. Animal studies}

Diets and procedure. C.D. rats ${ }^{2}$ were purchased in 32 groups of 6 male weanling litter mates. They were maintained on Purina rat chow diet and tap water ad libitum until they reached a weight of 75 to $175 \mathrm{~g}$, at which

${ }^{2}$ Charles River Laboratories, Boston, Mass. time they were housed in individual bottom wired cages and given liquid diets in graduated drinking tubes (11) as the only source of food and water. The dietary composition has been represented in Figure 1. The diets contained 0.6 to 1 calorie per $\mathrm{ml}$, an adequate water/ calorie ratio for the rat (12). The salt formula of Hegsted, Mills, Elvehjem, and Hart (13) and the amino

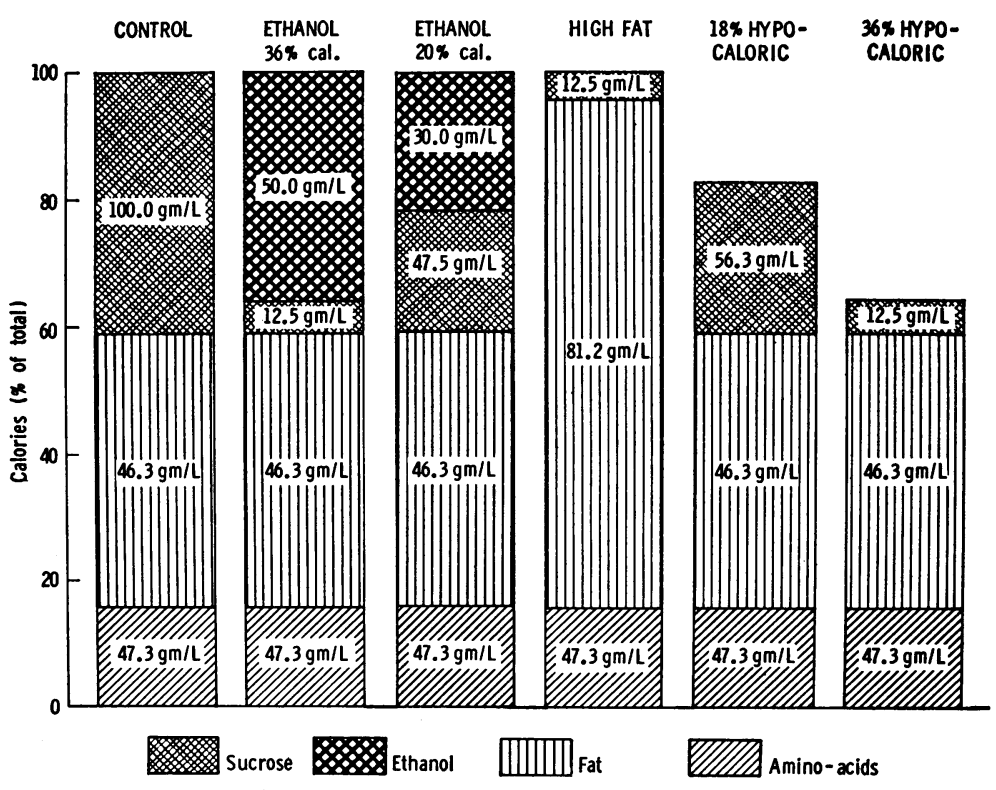

Choline Cl. $-0.25 \mathrm{gm} / \mathrm{L}$, Vitamins $-0.05 \mathrm{gm} / \mathrm{L}$, Salts $-10.00 \mathrm{gm} / \mathrm{L}$, Sod. Carrageenate $-4.00 \mathrm{gm} / \mathrm{L}$

Fig. 1. Composition of the SIX types of LiQUid DIETS FED to RATS. 
acid and vitamin mixtures of Sidransky and Farber (14) (with a $50 \%$ increase of niacin) were used. The choline and methionine contents were 0.25 and $1.50 \mathrm{mg}$ per $\mathrm{ml}$, respectively, which is equivalent to concentrations of 0.1 and $0.6 \%$ in solid diets, amounts found to be optimal for the rat (15). Fat was incorporated as an oil mixture containing, by weight, 5 parts of Mazola corn oil, 1.5 parts of cod liver oil (U.S.P.), and 12 parts of Pastene olive oil; sodium carrageenate (Viscarin) ( $4 \mathrm{~g}$ per $\mathrm{L}$ ) was used to stabilize the liquid diet. The control diet contained $16 \%$ of its calories as amino acids, $41 \%$ as sucrose, and $43 \%$ as fat (Figure 1) A preliminary study in 20 rats ( 75 to $95 \mathrm{~g}$ ) fed the control liquid diet or Purina rat chow ad libitum indicated similar growth rates of approximately $6 \mathrm{~g}$ per day, after an initial adaptation period of 3 to 5 days. In the alcohol diets, sucrose was replaced isocalorically with ethanol to the extent of $36 \%$ or $20 \%$ of total calories (Figure 1). Loss of ethanol by evaporation was negligible in the diets kept in the drinking tubes for periods up to 48 hours. In the high fat diet, sucrose ( $36 \%$ of calories) was replaced with the oil mixture, leading to a total fat content of $79 \%$ of the total calories (Figure 1). Two hypocaloric diets were also prepared by omitting sucrose from the control diet to the extent of 18 or $36 \%$ of the total calories (Figure 1).

Ethanol was introduced into the diet gradually. The final concentration of $50 \mathrm{~g}$ per $\mathrm{L}$ of ethanol was achieved on the fifth day of feeding. During the first 2 days, the animals were given the liquid diet with $30 \mathrm{~g}$ per $\mathrm{L}$ ethanol, which was increased to $40 \mathrm{~g}$ per $\mathrm{L}$ for the third and fourth days. The high fat diet was administered with a similar stepwise increase. The rats were studied in groups of two to four littermates. Observations during the initial days indicated in each group which of the animals had the lowest spontaneous food intake. This rate limiting rat (which was usually the one given alcohol) received the liquid diet ad libitum, and its pair-fed littermates were fed isocaloric amounts of one of the other diets on the following day. During the 24 hours preceding the sacrifice of the rats, the diets were given in three divided doses at approximately 8-hour intervals.

The body weight of the rats was determined at least twice a week. After 10 or 24 days, the animals were sacrificed by decapitation, blood was collected from the neck vessels, and serum was frozen at $-18^{\circ} \mathrm{C}$ until analysis. Samples of hepatic, pancreatic, and small intestinal tissue were fixed in $10 \%$ neutral formalin until processing for histological examination.

Chemical assays. Hematocrits were measured by the microprocedure. Total lipids were extracted from approximately $1 \mathrm{~g}$ of liver (16) and quantitated by the weight of the dried extract. Lipid classes were fractionated by silicic acid column chromatography and quantitated as described previously (17). In eight rats, fat free dry weight of the livers was determined, and the lipid content was expressed per gram of fat free dry weight, per gram of fat free wet weight, and per gram of wet weight. The relative change in lipid content produced by ethanol was found to be the same when ex- pressed per fat free dry or wet weight and not substantially different when calculated per gram of wet weight; subsequent results were expressed per wet weight of liver only. The results obtained in each animal were conpared to the corresponding values in the pair-fed control littermate, and the mean of the individual differences was calculated and the degree of significance was tested by the Student $t$ test (18).

\section{A. Clinical studies}

\section{Results}

The liver biopsies done in the five individuals studied under metabolic ward conditions showed fat accumulation in the liver after ingestion of ethanol, either as isocaloric substitution of carbohydrate (Figures 2 to 4 ) or in addition to the basic diet (Figure 5). Although the liver biopsies done during the control period indicated normal hepatic morphology, vacuoles filled with fat (confirmed by Sudan IV stains, Figures 2b', $2 c^{\prime}$ ) appeared during alcohol administration. Individual variation was apparent, and the distribution of the fat was irregular, with marked accumulation in some areas, whereas in others fat infiltration was less pronounced. No preferential localization of the fat within central, midzonal, or periportal hepatic lobular areas was apparent. In Subject 4, given up to $300 \mathrm{~g}$ of ethanol per day (Figure 5), fat accumulation was already visible by 8 days (Figure $5 \mathrm{~b}$ ), whereas in Subject 5, given half this amount, no lesion was visible after 8 days, but fatty infiltration was present after 21 days, similar in degree to the one found in Subject 3 (Figure $4 \mathrm{~b}$ ). The other three subjects who developed fatty livers were

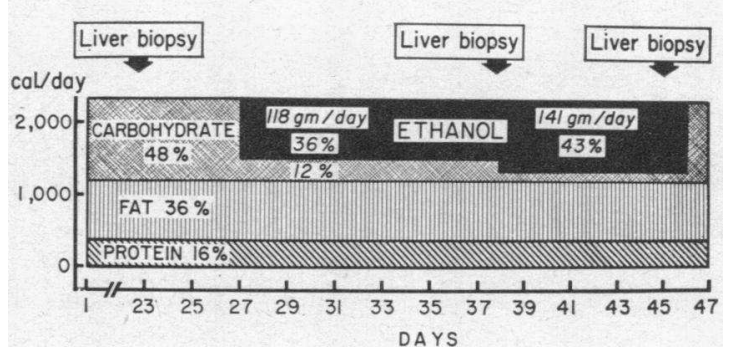

Fig. 2. SCHEME OF THE composition OF THE DiET AND ITS RELATIONSHIP TO THE LIVER BIOPSIES DONE IN SUBJECT 1 BEFORE (2A, $\mathrm{A}^{\prime}$ ) AND AFTER 11 DAYS (2B, B') OR 18 DAYS (2c, $c^{\prime}$ ) OF ISOCALORIC SUBSTITUTION OF CARBOHYDRATE BY ETHANOL. The daily dose of ethanol is indicated both in grams and as per cent of the total daily caloric intake. $2 a, b, c$ : hematoxylin eosin stains; $2 a^{\prime}, b^{\prime}, c^{\prime}$ : Sudan IV stains. 

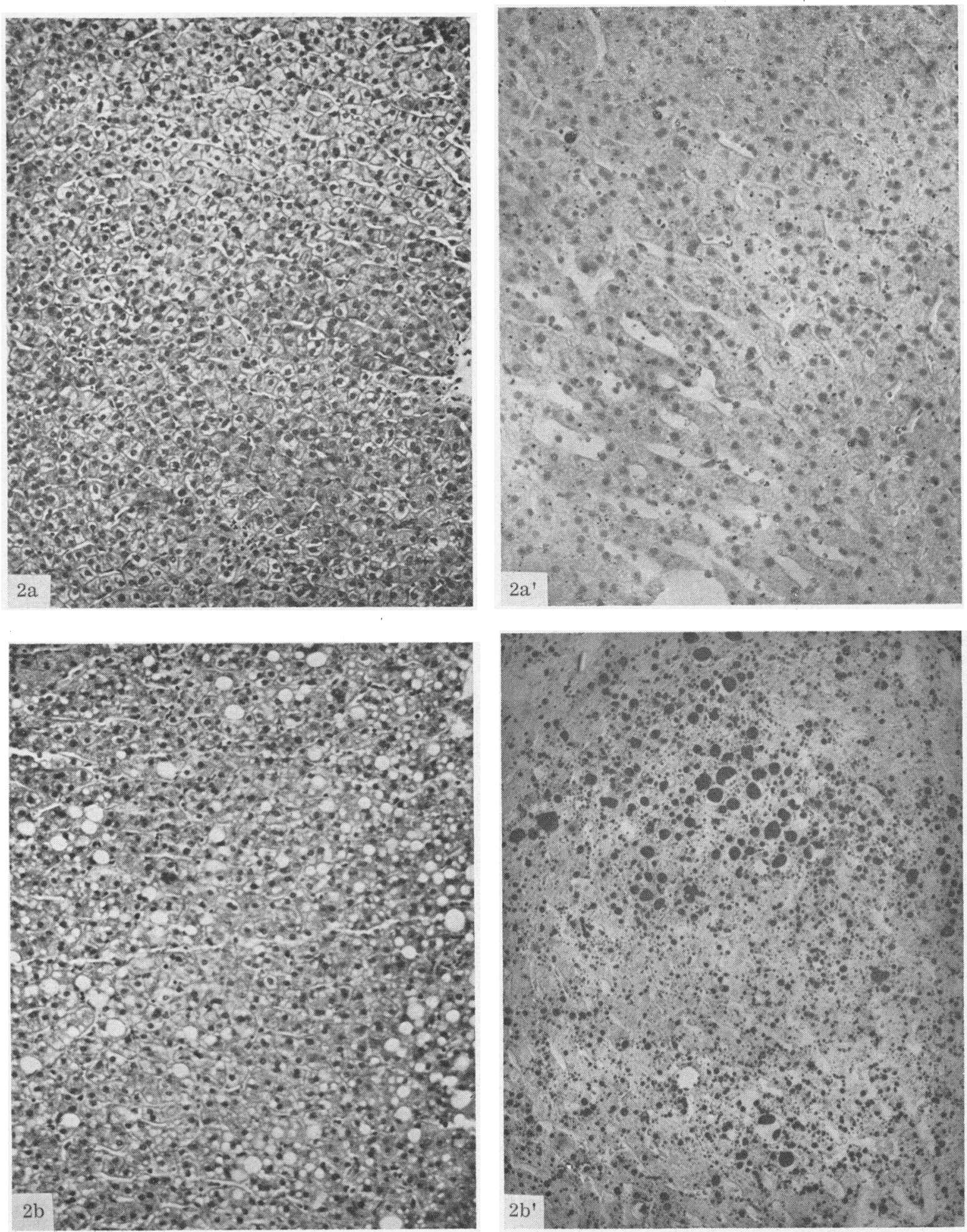

FIG. 2.-(Continued) 

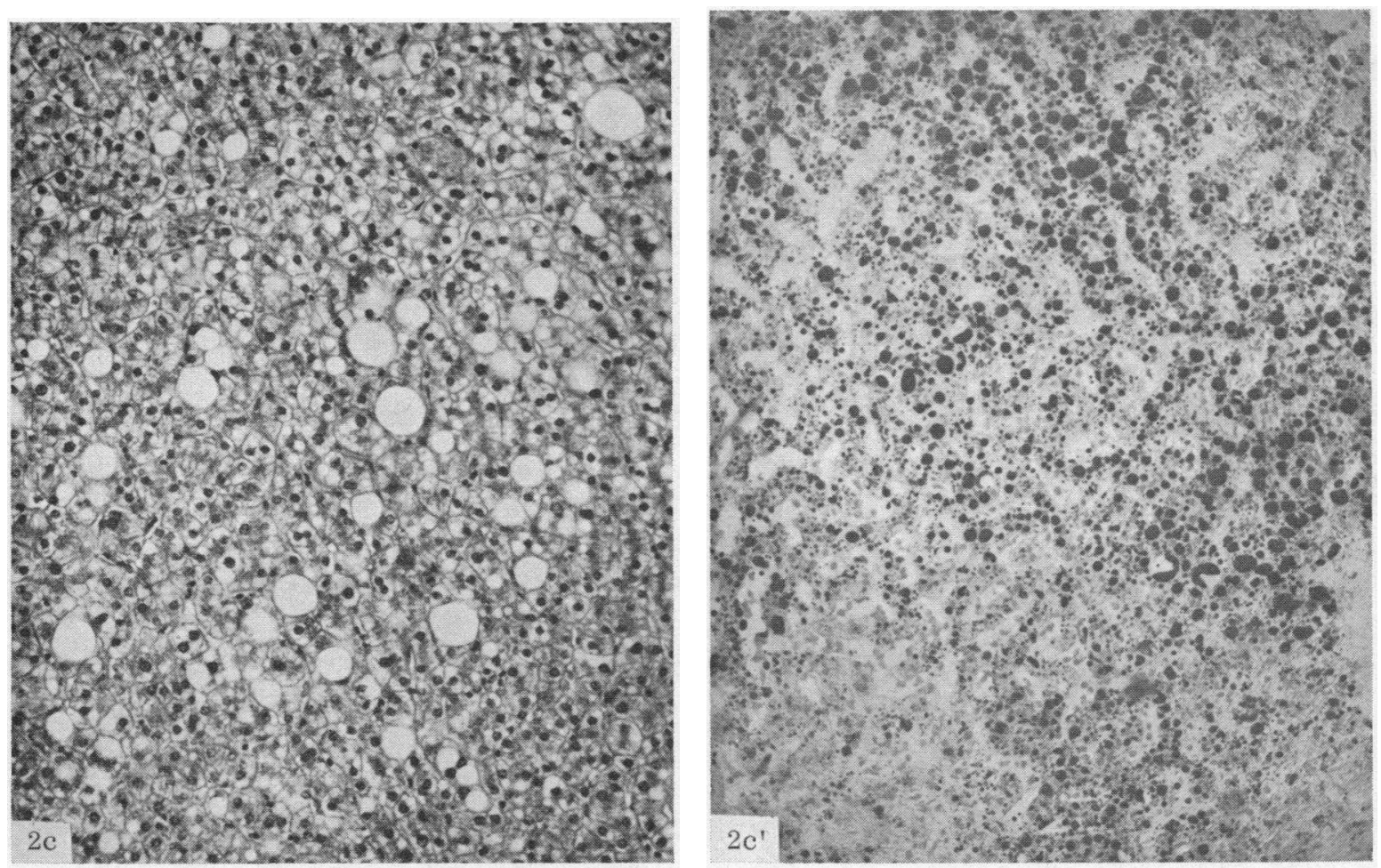

FIg. 2.-(Continued)

biopsied after 11 or more days of ethanol intake (Figures 2 to 4 ). Subjects 1 and 2 were biopsied twice during the ethanol phase; the last biopsies revealed more hepatic fat vacuoles. Subjects 3 and 4 were biopsied 1 month after ethanol withdrawal, and hepatic morphology was found to be restored to normal (Figures $4 c$ and $5 c$ ).

As indicated in Figure 5, addition of ethanol to a regular diet in amounts up to $300 \mathrm{~g}$ per day resulted in a marked rise of plasma glycerides accompanying the development of hepatic steatosis. In the other four individuals, given about half this dose or less of ethanol, no significant change was observed in circulating glycerides.

The serum ethanol concentrations observed in the individual given the largest dose of ethanol have been represented in Figure 5. Peak values of about $200 \mathrm{mg}$ per $100 \mathrm{ml}$ were observed. In the four other individuals, given lesser amounts of ethanol, serum alcohol levels were only moderately increased, varying between 30 and 100 mg per $100 \mathrm{ml}$.

No significant changes were found in plasma glucose, blood hematocrits, serum amylase, or in liver function tests or body weight (Table I).

\section{B. Animal studies}

Total hepatic lipids were similar in a group of ten rats given Purina chow diet ad libitum (41.6 $\pm 0.9 \mathrm{mg}$ per $\mathrm{g}$ of liver) and in the various series of animals fed the sucrose control diet in pairfeeding with the different alcohol groups, as indicated below and in Table II. Detailed analysis of hepatic lipids was done in 14 pairs of rats treated for 10 days and 19 pairs of rats treated for 24 days with the $5 \%$ ethanol diet $(36 \%$ of total calories) or the sucrose control diet (Table II). A striking progressive rise in total lipids was observed with ethanol, due predominantly to an accumulation of hepatic triglycerides, which increased on the average eightfold after 24 days. Ethanol given over 24 days resulted in an increase of liver weight, more than half of which could be accounted for by the excess lipid (Table II). The accumulation of lipid in the liver was accompanied by corresponding morphological changes. The histological appearance of a pair of rats with average hepatic lipid changes is indicated in Figure 6. Like the chemical results (Table II), morphological changes were more 


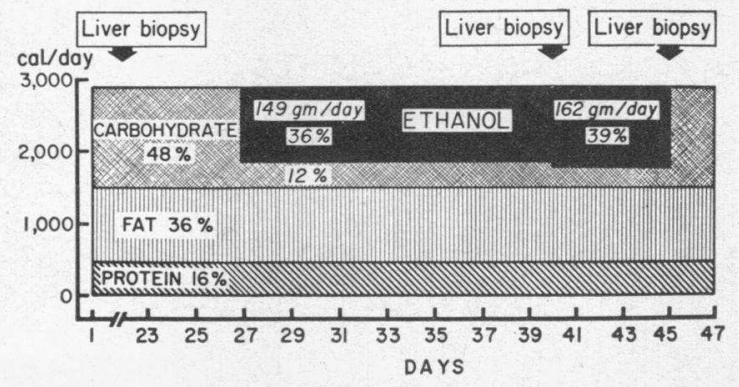

Fig. 3. Scheme of the composition of the Diet AND ITS RELATIONSHIP TO THE LIVER BIOPSIES (HEMATOXYLIN EOSin stains) DONE in Subject 2 Before (3A) AND AFter 13 DAYS (3B) OR 18 DAYS (3C) OF ISOCALORIC SUBSTITUTION OF CARBOHYDRATE BY ETHANOL. The daily dose of ethanol is indicated both in grams and as per cent of the total daily caloric intake.

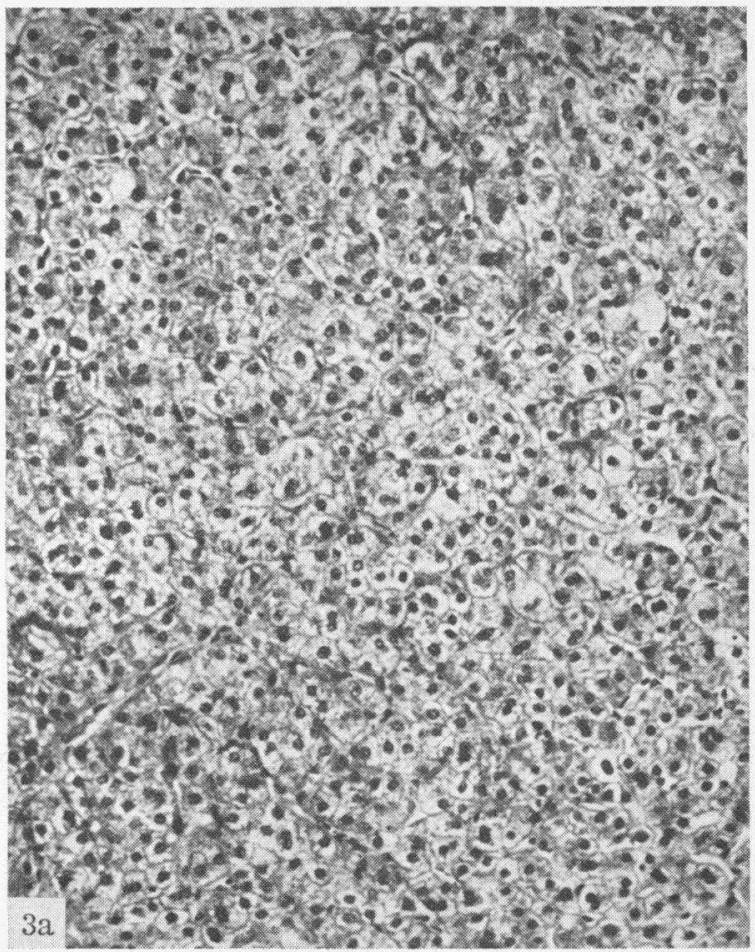

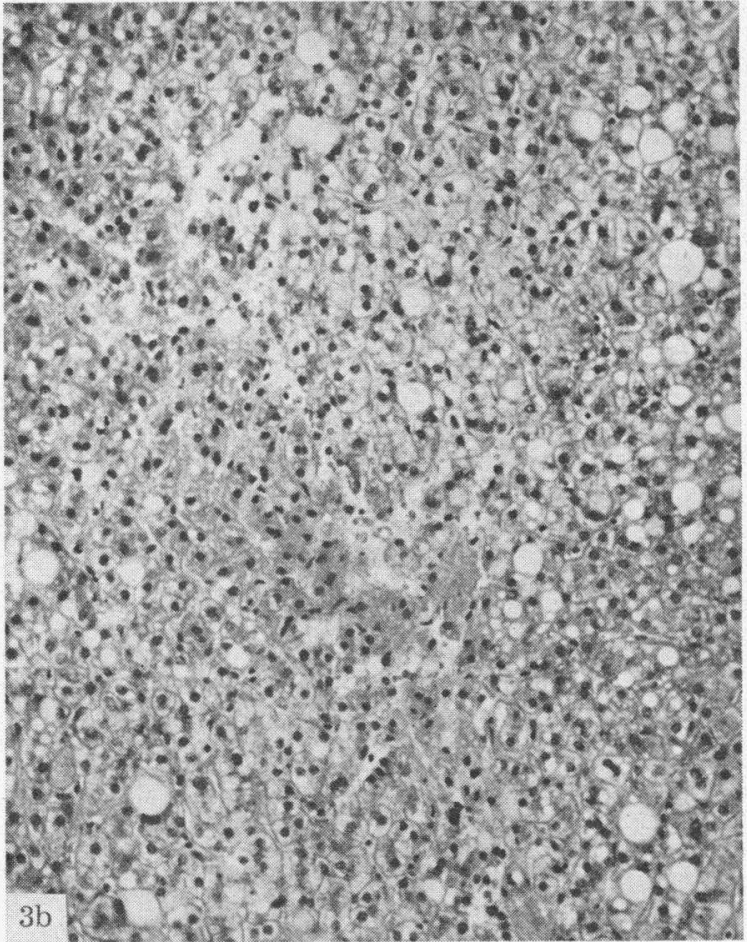

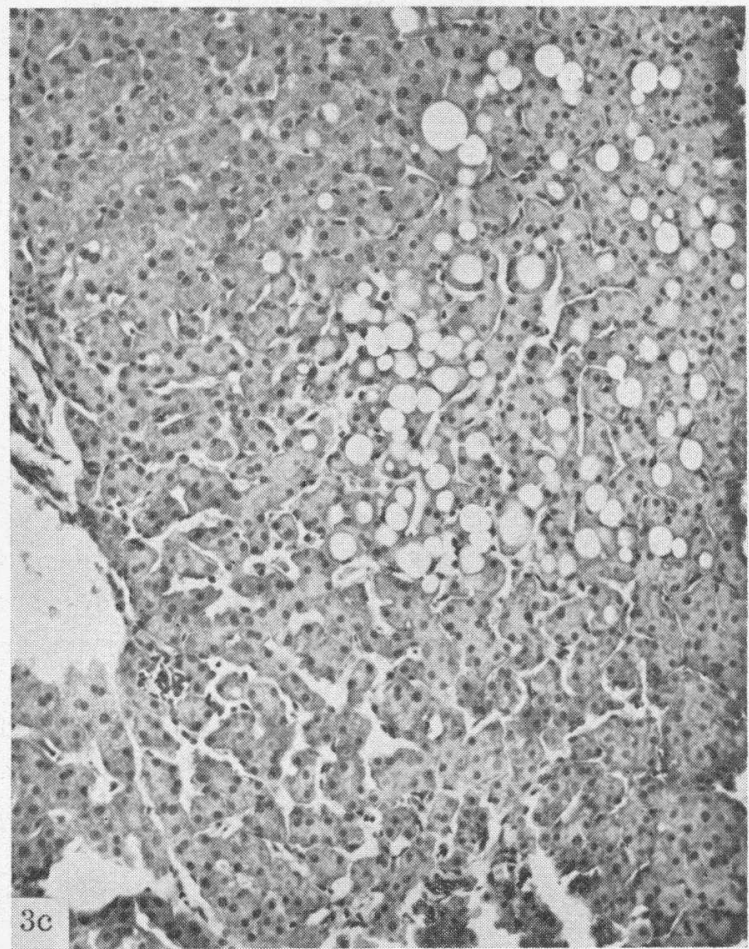

FIG. 3.-(Continued) 


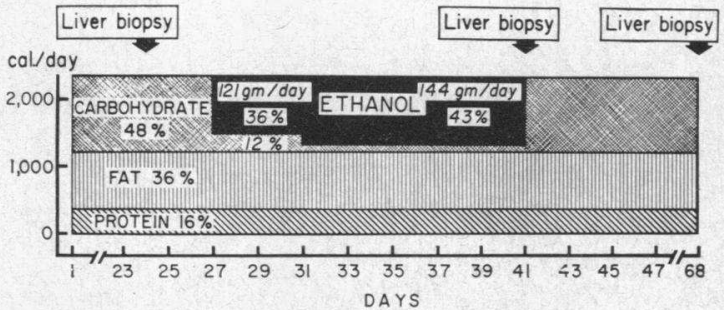

Fig. 4. Scheme of the composition of the diet AND ITS RELATIONSHIP TO THE LIVER BIOPSIES (HEMATOXYLIN EOSin STAINS) DONE IN SUbJect 3 Before (4A), AFTer 14 DAYS (4B) OF ISOCALORIC SUBSTITUTION OF CARBOHYDRATE BY ETHANOL, AND 4 WEEKS (4C) AFTER ETHANOL WITHDRAWAL. The daily dose of ethanol is indicated both in grams and as per cent of the total daily caloric intake.

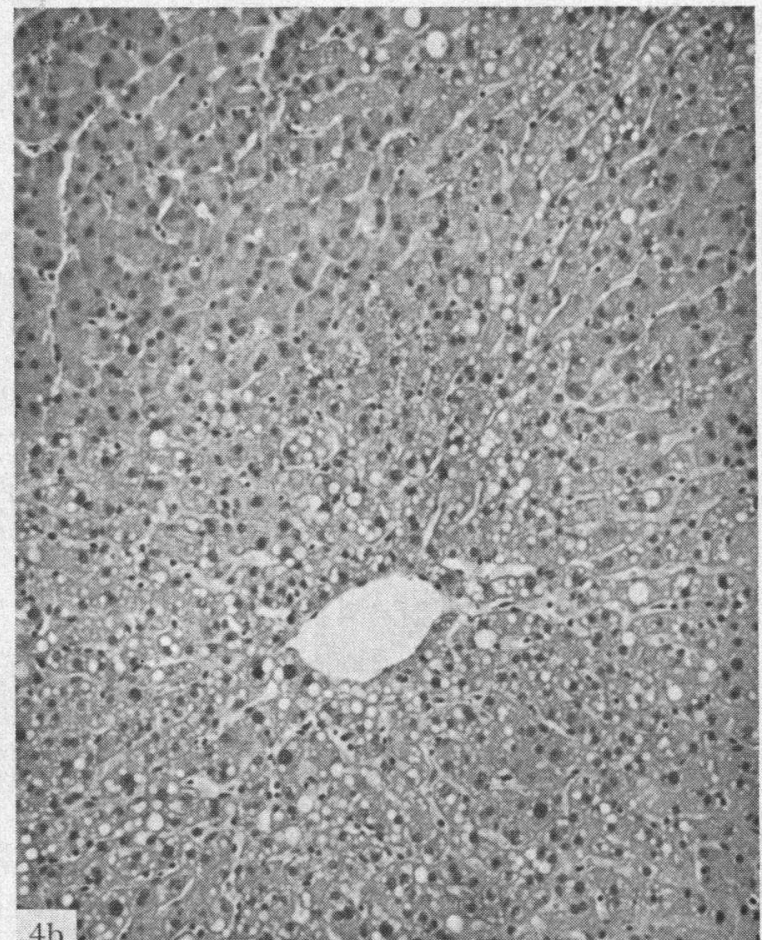

$4 b$

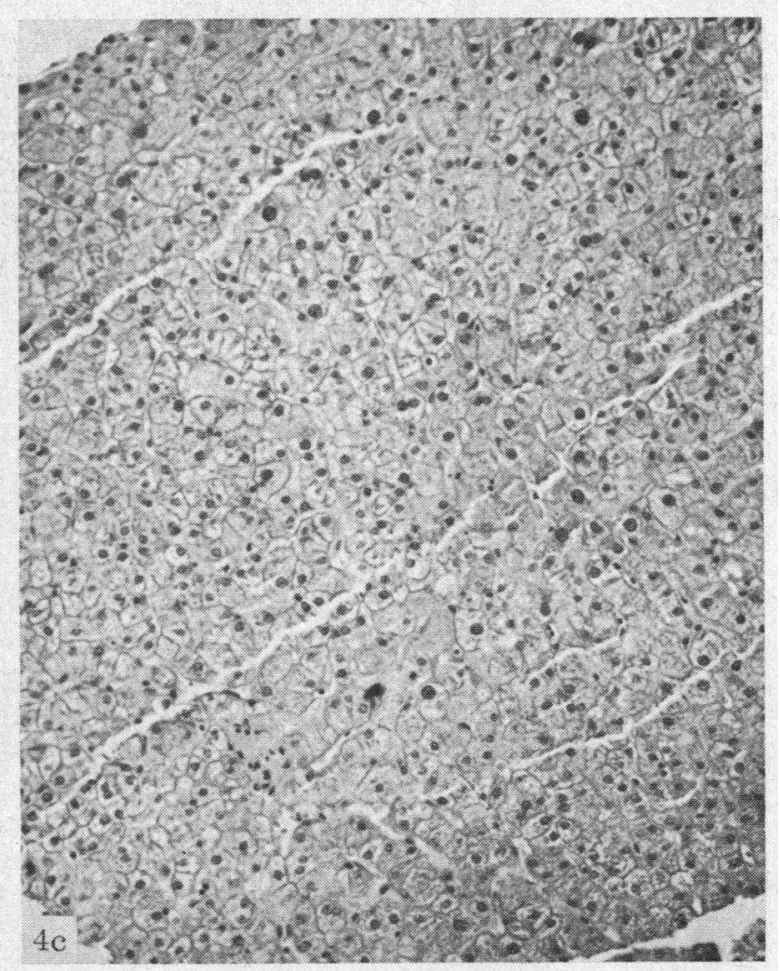

FIG. 4.-(Continued) 

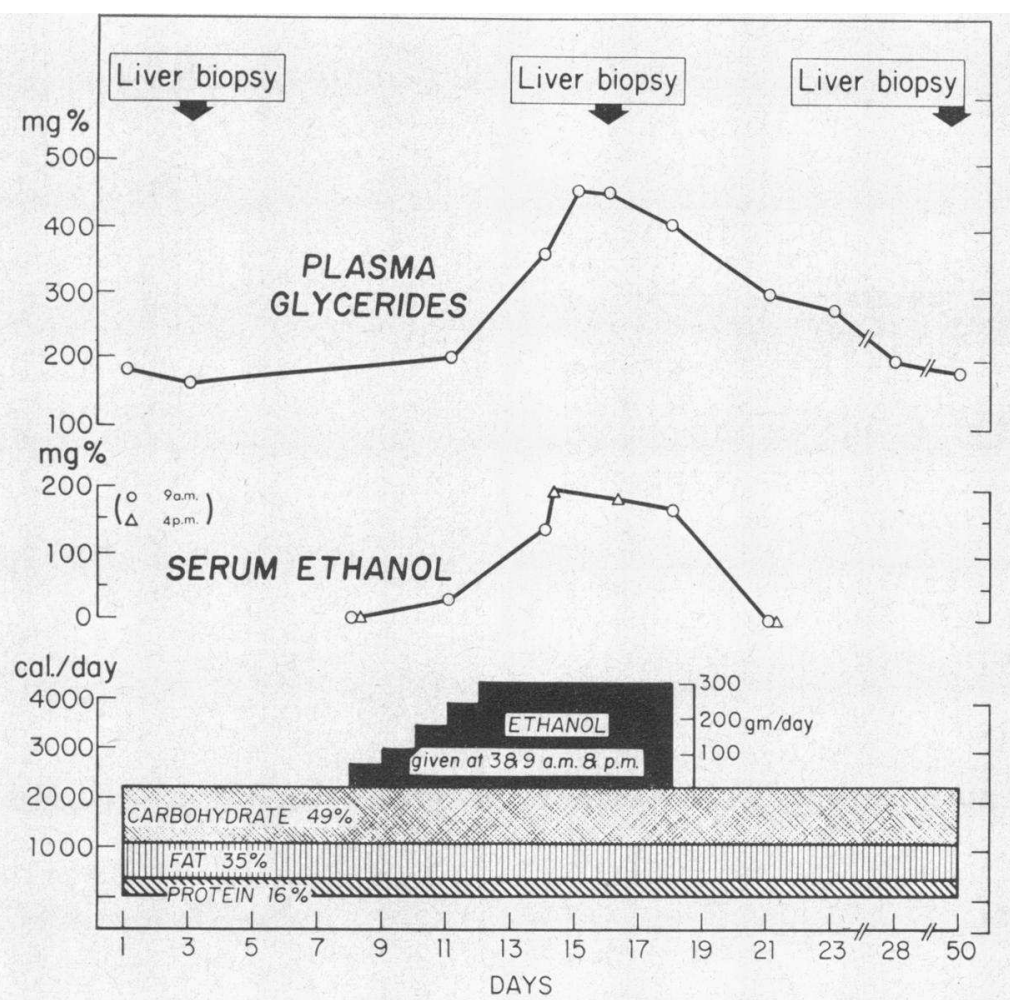

Fig. 5. Scheme of the COMPOSITION OF THE DIET AND ITS RELATIONSHiP TO THE HYPERGLYCERIDEMIA ASSOCIATED WITH THE INTAKE OF ALCOHOL AND to the liver biopsies (hematoxylin eosin stains) done in Subject 4 BEFORE (5A), AFTER 8 DAYS OF ETHANOL (5B), AND 1 MONTH AFTER ETHANOL WITHDRAWAL (5c).
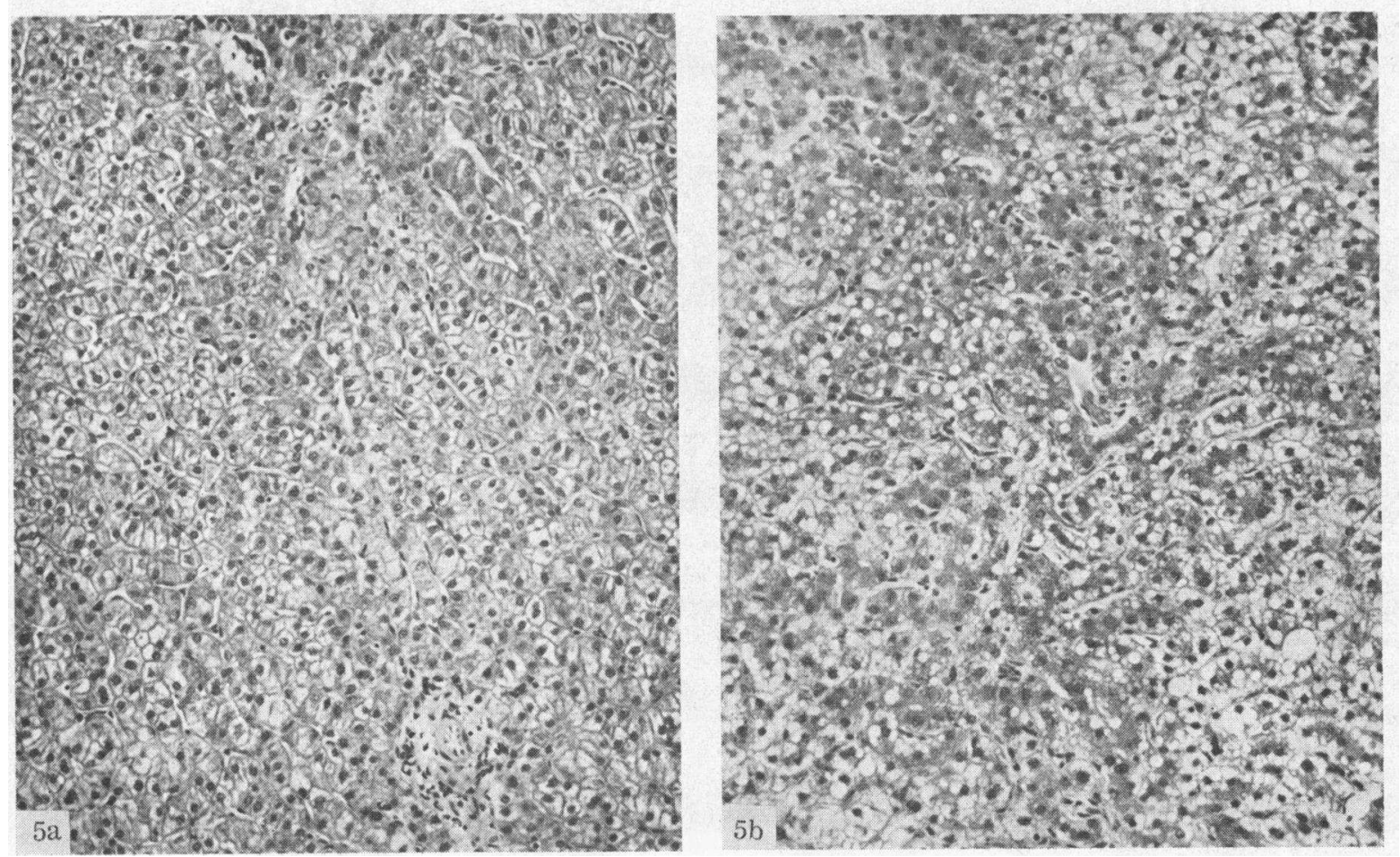

FIG. 5.-(Continued) 


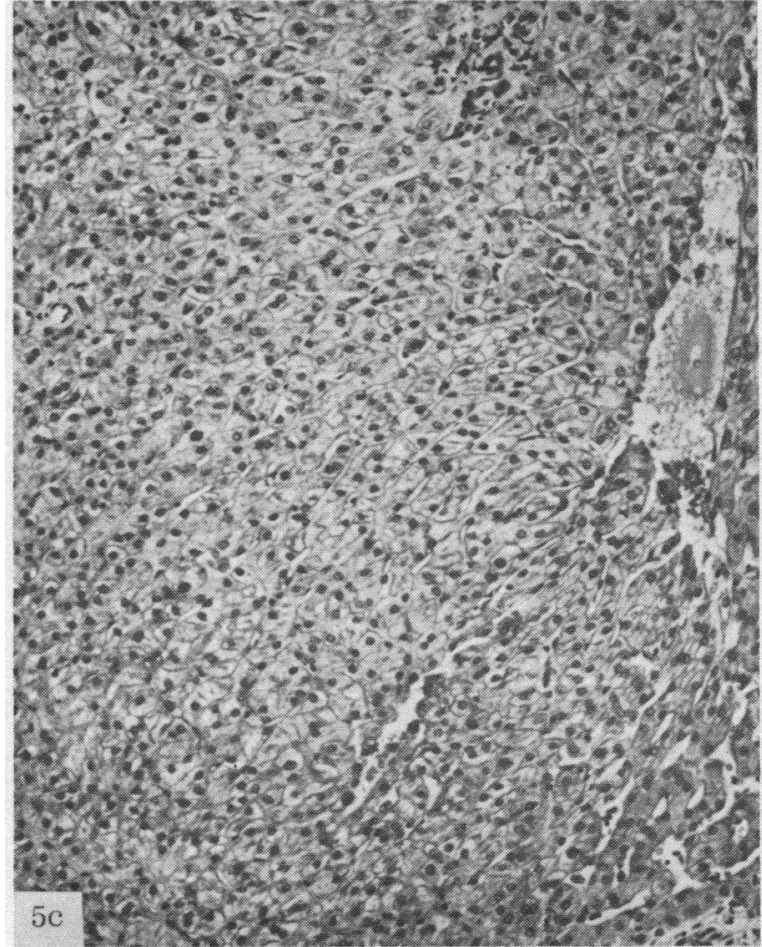

FIG. 5.-(Continued)

pronounced after 24 days of ethanol (Figure 6) than after 10 days. No morphological changes were observed in pancreas and small intestine.

After 24 days of the $3 \%$ ethanol diet (20\% of total calories), total lipids increased slightly to $67 \pm 7.5$ compared to $51.2 \pm 4.4 \mathrm{mg}$ per $\mathrm{g}$ in the pair-fed controls $(p<0.01)$. No significant changes in total hepatic lipids were observed in rats treated over 24 days with the high fat diet $(50.1 \pm 3.1$ compared to $45.5 \pm 3.1 \mathrm{mg}$ per $\mathrm{g}$ in the controls), the $18 \%$ hypocaloric diet (49.1 \pm 3.0 compared to $49.4 \pm 1.8 \mathrm{mg}$ per $\mathrm{g}$ in the controls), and the $36 \%$ hypocaloric diet $(50.6 \pm 2.7$ compared to $50.6 \pm 1.3 \mathrm{mg}$ per $\mathrm{g}$ in the controls).

Animals fed the ethanol diet had a significantly lower growth rate than the littermates pair-fed daily with isocaloric amounts of the control sucrose diet: in a group of 34 pairs of rat littermates fed with liquid diets over 24 days, the average daily weight gain was $2.28 \pm 0.17 \mathrm{~g}$ for the control rats, as compared to $1.86 \pm 0.16 \mathrm{~g}$ in the animals fed $5 \%$ ethanol diet $(\mathrm{p}<0.001)$. In the rats fed the $18 \%$ hypocaloric diet, the average daily weight gain $(1.79 \pm 0.38 \mathrm{~g})$ was comparable to that of the alcohol group, whereas the animals given the $36 \%$ hypocaloric diet had no significant change in weight. Growth rates of the controls and the rats given the diet rich in fat were similar.

Serum alcohol levels were determined at random at the time of sacrifice in 17 rats having free access to the alcohol diets: either $3 \%$ (6 rats) or $5 \%$ (11 rats). Serum alcohol concentrations were negligible in the rats given the $3 \%$ alcohol diet, whereas they averaged $63.7 \pm 12.6 \mathrm{mg}$ per $100 \mathrm{ml}$ in the group fed the $5 \%$ ethanol diet.

At the time of sacrifice, hematocrit values were similar in all groups.

\section{Discussion}

The major point of the present study was to determine whether both in man and in rats alcohol can produce fatty liver despite an otherwise adequate diet.

TABLE II

Effect of ethanol on hepatic lipid composition in two groups of rats treated for 10 or 24 days

\begin{tabular}{|c|c|c|c|c|c|c|}
\hline & \multicolumn{3}{|c|}{ A: 14 pairs of rats treated 10 days } & \multicolumn{3}{|c|}{ B : 19 pairs of rats treated 24 days } \\
\hline & Sucrose & Ethanol & p values* & Sucrose & Ethanol & p values* \\
\hline $\begin{array}{l}\text { Total lipids, } \\
\quad \text { mg liprd/g liver }\end{array}$ & $\begin{array}{r}40.9 \\
\pm 1.4\end{array}$ & $\begin{array}{r}80.3 \\
\pm 4.2\end{array}$ & $<0.001$ & $\begin{array}{r}43.2 \\
\pm 1.2\end{array}$ & $\begin{array}{l}129.4 \\
\pm 9.2\end{array}$ & $<0.001$ \\
\hline $\begin{array}{l}\text { Triglycerides, } \\
\quad \text { mg lipid/g liver }\end{array}$ & $\begin{array}{r}11.2 \\
\pm 1.4\end{array}$ & $\begin{array}{r}41.3 \\
\pm 4.3\end{array}$ & $<0.001$ & $\begin{array}{r}11.3 \\
\pm 1.3\end{array}$ & $\begin{array}{r}89.4 \\
\pm 11.1\end{array}$ & $<0.001$ \\
\hline $\begin{array}{l}\text { Phospholipids, } \\
\text { mg lipid/g liver }\end{array}$ & $\begin{array}{r}26.5 \\
\pm 0.9\end{array}$ & $\begin{array}{r}33.4 \\
\pm 1.3\end{array}$ & $<0.001$ & $\begin{array}{r}28.8 \\
\pm 1.2\end{array}$ & $\begin{array}{r}31.4 \\
\pm 1.1\end{array}$ & $<0.001$ \\
\hline $\begin{array}{l}\text { Liver weight, } \\
\text { g wet wt }\end{array}$ & $\begin{array}{r}7.30 \\
\pm 0.20\end{array}$ & $\begin{array}{r}7.41 \\
\pm 0.33\end{array}$ & $>0.10$ & $\begin{array}{r}7.33 \\
\pm 0.54\end{array}$ & $\begin{array}{r}8.82 \\
\pm 0.37\end{array}$ & $<0.001$ \\
\hline
\end{tabular}

* Ethanol vs. sucrose. 

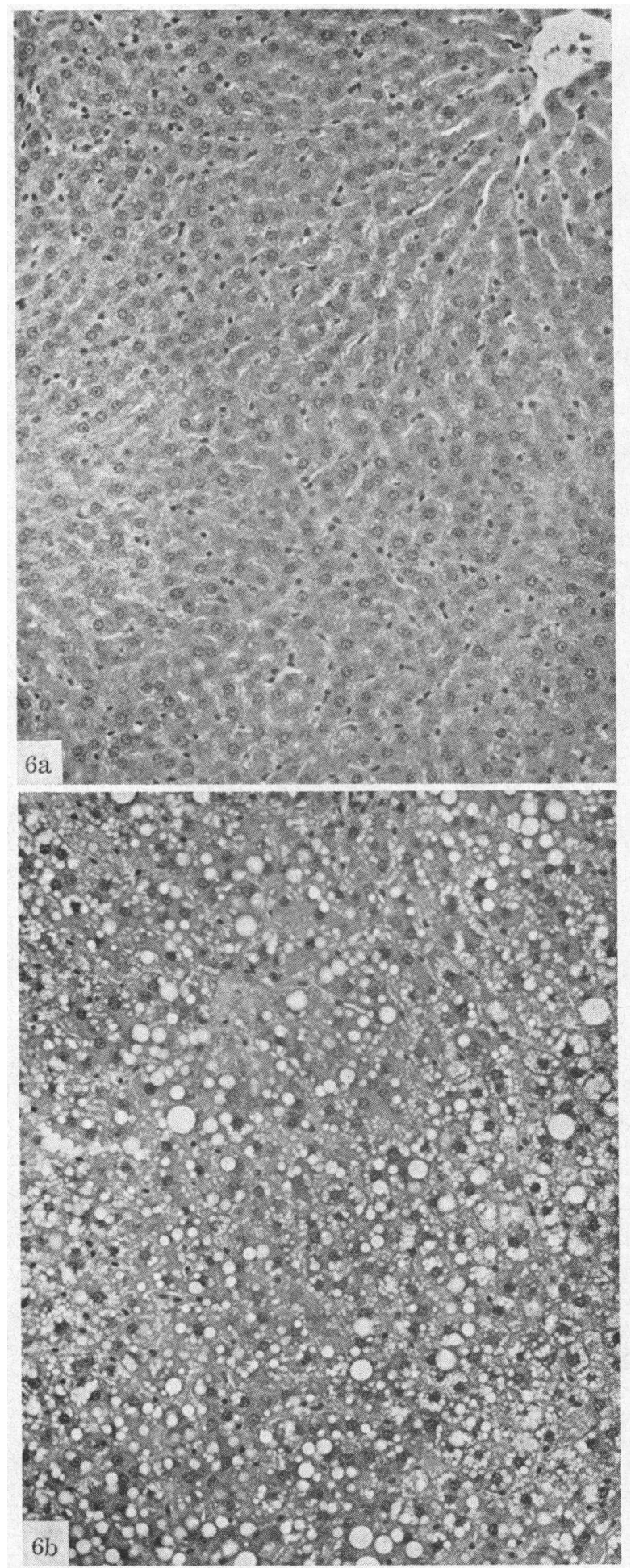

Fig. 6. Livers of TWO RAT LITTERMATES PAIR-FED OVER 24 DAYS WITH ISOCALORIC AMOUNTS OF A) THE CONTROL DIET OR B) THE ETHANOL DIET ( $36 \%$ OF TOTAL CALORIES). Hematoxylin eosin stains. Total lipids were 46 (a) and 119 (b) mg per $\mathrm{g}$.
Previously, Volwiler, Jones, and Mallory (19) and Summerskill, Wolfe, and Davidson (20) failed to detect a deleterious effect of alcohol administered to patients recovering from alcoholic fatty liver. In their studies, however, the amounts of alcohol given were less than in our investigation and much less than the usual intake of alcoholics. In contrast, Menghini (21) found, with presumably larger amounts of alcohol, that clearing of the fat from alcoholic fatty livers was prevented by alcohol ingestion. Recently Erenoglu, Edreira, and Patek (22) gave amounts of alcohol similar to the ones used in the present investigation to subjects with pre-existing cirrhosis and failed to detect harmful effects on the cirrhosis, but mild fat accumulation was noted on histological examination.

All the preceding studies were concerned with the effect of alcohol in subjects with fatty liver or cirrhosis, leaving the question unanswered as to whether in subjects with morphologically normal livers, ingestion of alcohol in a dose approaching amounts usually consumed by alcoholics is capable of producing fat accumulation, even in the absence of dietary deficiencies.

Our data demonstrate that in subjects with a history of alcoholic fatty liver, but whose hepatic morphology has returned to normal, accumulation of fat in the liver can be produced by the consumption of relatively moderate amounts of alcohol, either in addition to or as isocaloric substitution for carbohydrate in an otherwise adequate diet. In man, fat accumulation was not quantitated chemically. On histological examination, it appeared to be moderate and less pronounced than the marked steatosis that can sometimes be seen in patients hospitalized for alcoholic liver disease. The mildness of the fat accumulation under the present experimental conditions appears to be linked, at least in part, to the relatively modest dose of alcohol, which was in every instance much less than the spontaneous intake of these individuals when on an alcoholic debauch.

The steatosis appeared to depend on both the dose and the duration of ethanol intake, but in the limited number of subjects studied, it was not possible to establish whether a threshold exists for the production of fatty liver by ethanol. It is possible that our subjects, who had a history of alcoholic fatty liver, may indeed be more 
susceptible to an alcoholic insult than an alcoholic individual without previous fatty liver or than an average nonalcoholic subject. Prolonged administration of ethanol to nonalcoholic subjects, however, may be objectionable; therefore rats were used to determine whether, in the absence of preexisting alcoholism, ethanol consumption is capable of producing fatty livers, despite an adequate diet.

With conventional feeding techniques, rats refuse to drink spontaneously amounts of alcohol substantially greater than about $20 \%$ of the calories. In previous studies, this dose of ethanol (given with an adequate diet) resulted in some accumulation of hepatic lipids, detectable with chemical methods, but no actual fatty liver was produced, as seen by gross or morphological examination $(23,24)$. This lack of effect is not surprising, as $20 \%$ of total caloric intake as alcohol is a very low dose which, under our experimental conditions, not only failed to produce appreciably fatty livers, but also did not result in any significant blood level of alcohol. Previous investigators succeeded in producing fatty livers in rats through the combination of alcohol with dietary deficiencies $(4,25)$. These experiments led to two concepts regarding pathogenesis: either that the fatty liver is due to dietary deficiencies associated with the caloric load of ethanol rather than to ethanol itself (4) or that the effect of dietary deficiencies is potentiated by alcohol, through enhancement of choline requirements independent of the increase in caloric intake (25).

To determine whether hepatic steatosis can be produced in rats with ethanol in the absence of any dietary deficiencies, an experimental method was needed to increase the amounts of alcohol consumed by the rats. When given acutely without food in a large single dose by gastric tube, alcohol was found to produce fat accumulation in the liver (26-30), but the mechanisms involved in these acute experiments do not necessarily apply to more prolonged alcohol intake, such as is observed commonly in chronic alcoholic patients.

In the present study, prolonged intake of substantial amounts of alcohol was achieved by overcoming the natural aversion of rats for alcohol through incorporation of the ethanol in a completely liquid diet with the exclusion of any other source of food or fluid. With this experimental design, the amount of alcohol ingested could be raised to $36 \%$ of total calories. The nutritional adequacy of this diet was evidenced by continued growth as well as normal hepatic morphology and fat content in the controls. This amount of alcohol resulted in moderate serum alcohol levels and was sufficient to consistently produce hepatic steatosis, with an average eightfold rise of hepatic triglycerides after 24 days (Table II).

Despite isocaloric pair-feeding, the rate of growth was significantly less in animals on alcohol as compared to the controls. This confirms previous studies indicating that alcohol does not support growth as well as carbohydrate (12, $24,31)$. The lesser gain in body weight seen in the animals given alcohol suggests that either alcohol, in some way, affects food utilization or increases caloric loss, or that the calories from ethanol are less available for growth. Hypocaloric diets, however, produced no steatosis, indicating that the alcoholic fatty liver was not simply a result of a lack of available calories. Although the animals given alcohol achieved less total body weight than the controls, the weight of their livers was significantly increased, which was due, to a large degree, to fat accumulation (Table II).

That the fatty liver associated with isocaloric substitution of carbohydrate by alcohol is due to a specific effect of alcohol itself rather than to some nonspecific change of the diet (for instance, a decrease in carbohydrate content) was also indicated by the experiments with the high fat diet. When $36 \%$ of the total calories given as carbohydrate in the control diet was replaced with fat instead of alcohol, no fatty liver occurred, indicating that the capacity of alcohol for producing a fatty liver is greater than that of fat itself.

Possible mechanisms responsible for the hepatic steatosis have not been assessed directly in the present study, but the observed blood lipid changes contribute indirectly to the understanding of the pathogenesis of this type of fatty liver. It has been postulated that fat accumulation could result from a decrease in lipoprotein release from the liver (32). Although this possibility has not been ruled out, the fact that a fatty liver was observed simultaneously with the development of hyperglyceridemia (Figure 5) and that alcohol has been shown previously to produce hyperglyceri- 
demia $(1,5,17,29,33)$ suggests that decreased hepatic glyceride release does not represent a primary cause for fatty liver development, at least not during the initial period.

After the acute administration of a large single dose of alcohol to rats, fat that accumulated in the liver resembled adipose tissue lipids (29), incriminating increased peripheral fat mobilization as a mechanism for the hepatic steatosis. The latter experimental model, however, differs markedly from the experimental design used in the present study in which hepatic fat accumulation was produced by the repeated administration over prolonged periods of time of more moderate doses of alcohol. With prolonged ethanol intake, fat that accumulated in the liver, both in man and in rats, differed markedly from adipose tissue lipids, indicating that fat depots do not represent a major source for the lipids of this type of alcoholic fatty liver (34). Theoretically, hepatic steatosis produced by prolonged alcohol ingestion could be due to increased hepatic lipogenesis or to an interference by ethanol with hepatic lipid disposition. Ethanol has been found to increase hepatic production of fatty acids (35) and triglyceride (29) and to decrease hepatic fatty acid oxidation, both in vitro (35) and in vivo (30). Some of these effects appear to be linked to the generation of reduced nicotinamide adenine dinucleotide produced by the oxidation of ethanol in the liver $(6,35)$. Theoretically, all these mechanisms, as well as some additional possibilities (36), including hepatic deposition of dietary fatty acids (34), could play a role in the fatty liver produced with ethanol.

\section{Summary}

1. In studies performed under metabolic unit conditions in five alcoholic subjects, isocaloric substitution of carbohydrate by ethanol in an otherwise normal diet or addition of ethanol to an adequate diet resulted in fat accumulation in the liver. This incriminates ethanol itself as a direct etiologic factor in the pathogenesis of the alcoholic fatty liver, independent of nutritional deficiencies.

2. The natural aversion of rats for alcohol was overcome by incorporating ethanol in a liquid diet. With this feeding technique, the spontane- ous ethanol intake was almost twice as high as with conventional feeding procedures and became comparable to the amounts used in the clinical studies ( $36 \%$ of total calories). As in man, isocaloric replacement of sucrose $(36 \%$ of total calories) by ethanol produced fatty liver. After 24 days of treatment, the average hepatic triglyceride increase was eightfold. Only a minimal effect was observed when the ethanol dose was reduced to $20 \%$ of total calories.

3 . In rats given liquid diets, isocaloric replacement of ethanol by fat did not produce hepatic steatosis, demonstrating that the capacity of ethanol for generating fatty livers is greater than that of fat itself. No fatty liver developed when sucrose (to the extent of 18 or $36 \%$ of total calories) was omitted from the control diet, indicating that the steatosis observed with isocaloric substitution of sucrose by ethanol was not simply due to a lack of carbohydrate calories.

4. Rats fed the ethanol-containing diet had less total body weight gains than the controls, indicating that ethanol supports growth less well than sucrose. The livers of the ethanol-fed rats were heavier, however, largely due to fat accumulation.

\section{Acknowledgments}

The authors are grateful to Drs. C. S. Davidson and T. P. Almy for their continuous interest and help, to Drs. R. A. MacDonald and C. Solomon for special histological processing of the liver specimens, to the Misses E. Doyle, E. A. Greene, J. Hoffmann, H. Heiligstadt, and Mrs. B. Dallner for expert assistance, and to Mrs. W. Stocker, M. Wilson, and Miss F. Connally for preparation of the diets.

\section{References}

1. Lieber, C. S., D. P. Jones, J. Mendelson, and L. M. DeCarli. Fatty liver, hyperlipemia and hyperuricemia produced by prolonged alcohol consumption, despite adequate dietary intake. Trans. Ass. Amer. Phycns 1963, 76, 289.

2. Lieber, C. S., D. P. Jones, and L. M. DeCarli. The role of dietary factors in the pathogenesis of the alcoholic fatty liver (abstract). Gastroenterology 1964, 46, 303.

3. Addison, $T$. Observations on fatty degeneration of the liver. Guy's Hosp. Rep. 1836, 1, 476.

4. Best, C. H., W. S. Hartroft, C. C. Lucas, and J. H. Ridout. Liver damage produced by feeding alcohol or sugar and its prevention by choline. Brit. med. J. 1949, 2, 1001. 
5. Klatskin, G. Alcohol and its relation to liver damage. Gastroenterology 1961, 41, 443.

6. Lieber, C. S., and C. S. Davidson. Some metabolic effects of ethyl alcohol. Amer. J. Med. 1962, 33, 319.

7. Food and Nutrition Board. Recommended Dietary Allowances, 6th ed. Washington, D. C., National Academy of Sciences National Research Council, 1964, publication 1146.

8. Newman, E. J., and H. W. Newman. A microdiffusion method for alcohol determination. Stanf. med. Bull. 1953, 11, 96.

9. Bragdon, J. H. Extraction of lipids from serum in Lipids and the Steroid Hormones in Clinical Medicine, F. W. Sunderman and F. W. Sunderman, Jr., Eds. Philadelphia, J. B. Lippincott, 1960, p. 6.

10. Van Handel, E., and D. B. Zilversmit. Micromethod for the direct determination of serum triglycerides. J. Lab. clin. Med. 1957, 50, 152.

11. Richter, C. P. A study of the effect of moderate doses of alcohol on the growth and behavior of the rat. J. exp. Zoology 1926, 44, 397.

12. Morgan, A. F., L. Brinner, C. B. Plaa, and M. M. Stone. Utilization of calories from alcohol and wines and their effects on cholesterol metabolism. Amer. J. Physiol. 1957, 189, 290.

13. Hegsted, D. M., R. C. Mills, C. A. Elvehjem, and E. B. Hart. Choline in the nutrition of chicks. J. biol. Chem. 1941, 138, 459.

14. Sidransky, H., and E. Farber. Sex difference in induction of periportal fatty liver by methionine deficiency in the rat. Proc. Soc. exp. Biol. (N. Y.) 1958, 98, 293.

15. Treadwell, C. R. Growth and lipotropism I. The dietary requirements of methionine, cystine, and choline. J. biol. Chem. 1945, 160, 601.

16. Folch, J., M. Lees, and G. H. S. Stanley. A simple method for the isolation and purification of total lipides from animal tissues. J. biol. Chem. 1957, 226, 497.

17. Jones, D. P., M. S. Losowsky, C. S. Davidson, and C. S. Lieber. Effects of ethanol on plasma lipids in man. J. Lab. clin. Med. 1963, 62, 675.

18. Snedecor, G. W. Statistical Methods 5th ed. Ames, Iowa, Iowa State College Press, 1956.

19. Volwiler, W., C. M. Jones, and T. B. Mallory. Criteria for the measurement of results of treatment in fatty cirrhosis. Gastroenterology 1948, 11, 164.

20. Summerskill, W. H. J., S. J. Wolfe, and C. S. Davidson. Response to alcohol in chronic alcoholics with liver disease. Clinical, pathological, and metabolic changes. Lancet $1957,1,335$.

21. Menghini, G. L'aspect morpho-bioptique du foie de l'alcoolique (non cirrhotique) et son évolution. Bull. schweiz. Akad. med. Wiss. 1960, 16, 36.

22. Erenoglu, E., J. G. Edreira, and A. J. Patek, Jr. Observations on patients with Laennec's cirrhosis receiving alcohol while on controlled diets. Ann. intern. Med. 1964, 60, 814.
23. Klatskin, G., H. M. Gewin, and W. A. Krehl. Effects of prolonged alcohol ingestion on the liver of the rat under conditions of controlled adequate dietary intake. Yale J. Biol. Med. 1951, 23, 317.

24. Mallov, S. Effect of chronic ethanol intoxication on liver lipid content of rats. Proc. Soc. exp. Biol. (N. Y.) 1955, 88, 246.

25. Klatskin, G., W. A. Krehl, and H. O. Conn. The effect of alcohol on the choline requirement $I$. Changes in the rat's liver following prolonged ingestion of alcohol. J. exp. Med. 1954, 100, 605.

26. Mallov, S., and J. L. Bloch. Role of hypophysis and adrenals in fatty infiltration of liver resulting from acute ethanol intoxication. Amer. J. Physiol. 1956, 184, 29.

27. DiLuzio, N. R. Effect of acute ethanol intoxication on liver and plasma lipid fractions of the rat. Amer. J. Physiol. 1958, 194, 453.

28. Brodie, B. B., W. M. Butler, Jr., M. G. Horning, R. P. Maickel, and H. M. Maling. Alcohol-induced triglyceride deposition in liver through derangement of fat transport. Amer. J. clin. Nutr. 1961, 9, 432.

29. Horning, M. G., M. Wakabayashi, and H. M. Maling. Biochemical processes involved in the synthesis, accumulation and release of triglycerides by the liver in Mode of Action of Drugs: Effects of Drugs on Synthesis and Mobilization of Lipids, E. C. Horning, Ed. Oxford, Pergamon, 1963, vol. 2, p. 13.

30. Rebouças, G., and K. J. Isselbacher. Studies on the pathogenesis of the ethanol-induced fatty liver. I. Synthesis and oxidation of fatty acids by the liver. J. clin. Invest. 1961, 40, 1355.

31. Mitchell, H. H. The food value of ethyl alcohol. J. Nutr. 1935, 10, 311.

32. Schapiro, R. H., G. D. Drummey, Y. Shimizu, and K. J. Isselbacher. Studies on the pathogenesis of the ethanol-induced fatty liver. II. Effect of ethanol on palmitate-1- $C^{14}$ metabolism by the isolated perfused rat liver. J. clin. Invest. 1964, 43, 1338.

33. Losowsky, M. S., D. P. Jones, C. S. Davidson, and C. S. Lieber. Studies of alcoholic hyperlipemia and its mechanism. Amer. J. Med. 1963, 35, 794.

34. Lieber, C. S., and N. Spritz. Dietary, adipose tissue and newly synthesized fatty acids in the pathogenesis of the fatty liver produced by prolonged ethanol intake (abstract). Proceedings of the Annual Meeting of the American Association for the Study of Liver Diseases. Gastroenterology 1965, 48, 500 .

35. Lieber, C. S., and R. Schmid. The effect of ethanol on fatty acid metabolism; stimulation of hepatic fatty acid synthesis in vitro. J. clin. Invest. 1961, 40, 394.

36. Lieber, C. S. Pathogenesis of hepatic steatosis. Gastroenterology 1963, 45, 760. 